\title{
Kansainvälinen suomalainen elektronisen kirjallisuuden kenttä
}

Virpi Vairinen 
okturno.fi:n, Suomen ainoan digitaaliseen kirjallisuuteen kesN kittyvän julkaisualustan näkökulmasta ala näyttäytyy hyvin moninaisena. Se pitää sisällään paitsi suurelle yleisölle tuttua vakiintuneiden kustantamoiden julkaisemaa e- ja äänikirjallisuutta, myös runsaasti perinteisten instituutioiden ulkopuolella julkaistavaa, teknologisia mahdollisuuksia laajasti hyödyntävää elektronista kirjallisuutta. Varhaisimmat elektronisen kirjallisuuden teokset syntyivät aikana ennen internetiä, näitä olivat esimerkiksi Theo Lutzin 1959 ohjelmoima runogeneraattori sen tuottamine teksteineen sekä Christopher Stracheyn rakkauskirjegeneraattori vuodelta 1952 (Funkhauser 2007, 37; Joensuu 2012, 128). Nykyiselle kentälle internet on oleellinen osa teosten esilletuomista ja usein myös toteutusta (esim. Glazier 2002, 2-3). Suurten kustantamoiden ulkopuolella toimivilla tekijöillä on erilaisia tapoja suhtautua teostensa julkaisuun. Osan suhtautuminen muistuttaa internetin alkuaikojen yhteisöllisyydestä ja idealismista, jossa teosten ilmaisen jakamisen nähtiin johtavan alan kehittymiseen ja tekijöiden innon ylläpitämiseen paremmin kuin tuotteistamisen ja kaupallistamisen. Viime vuosina, kaupallisen internetin kasvettua, elektronisen kirjallisuuden helpommin standardoitavat muodot, kuten visuaaliset romaanit ja pelitaiteeseen nojaavat teokset, ovat vähitellen löytäneet tiensä digitaalisten sisältöjen nettikauppoihin. Vakiintuneita muotoja kaihtavat elektronisen kirjallisuuden teokset elävät kuitenkin yhä ensisijaisesti kansainvälisessä, ilmaiseen saatavuuteen perustuvassa yhteisössä.

Kustantamoiden e- ja äänikirjojen tuotanto nojaa suureen myyntivolyymiin ja mittavaan markkinointiin ja painottuu pääsääntöisesti proosakirjallisuuteen. Tavat hyödyntää digitaalisia mahdollisuuksia liittyvät ensisijaisesti digitaalisiin myyntialustoihin eikä teoksen julkaisu ääni- tai e-versiona yleensä tuo mukanaan median laajempaa hyödyntämistä. Suurten kustantamoiden tuotantoa leimaa myös perinteinen jako kotimaiseen ja käännöskirjallisuuteen ja monikieliset teokset koetaan usein vaikeasti markkinoitaviksi. On myös harvinaista, että kirjailija kirjoittaisi teoksen muulla kuin äidinkielellään.

Laajemmin digitaalisia keinoja hyödyntäviä elektronisen kirjallisuuden teoksia julkaistaan kansainvälisesti vain harvoin ja Suomessa ei juuri koskaan kustantamoiden listoilta. Teokset löytävätkin yleisönsä usein muiden taiteiden aloilta tuttuja esiintuomisen kanavia pitkin: netin julkaisualustoilla, näyttelyissä ja festivaaleilla. Osasyy tähän on alan monimuotoisuus, joka tuntuu jättävän sen kirjallisuuden vakiintuneiden institutionaalisten rakenteiden ulkopuolelle. Monimuotoisuus on paitsi kielellistä, myös ennen kaikkea lajihybridiyttä, jossa sekoittuvat niin kirjallisuuden lajit kuin taiteenlajitkin. Internetin julkaisualustat ovat tarjonneet kodin elektronisen kirjallisuuden kirjolle, kuten esimerkiksi tekstigeneraattoreille, hypertekstifiktiolle, visuaalisille romaaneille, videorunoudelle ja interaktiivisille tarinoille.

Suomalaisen digitaalisen runouden historiassa kansainvälisyydellä on erityisen suuri merkitys. Tähän on vaikuttanut perinteisesti teosten ilmainen 


\section{On myös mahdollista kysyä, onko kansainvälisyyttä kuvaavampi termi elektronisen kirjallisuuden alalle sittenkin transnationaalisuus.}

saatavuus netissä, mikä auttaa ylittämään maantieteellisiä rajoja, sekä englanninkielisyys, alkuperäisjulkaisuina tai käännettyinä, mikä vuorostaan auttaa ylittämään kielellisiä rajoja. Myös suomalaisista tekijöistä monet toteuttavat teoksiaan englanniksi. Nokturno.fi:n päätoimittajana teen työn alla olevasta numerosta ja virtuaalisen residenssimme asukkaan käyttämästä kielestä riippuen työtä englanniksi 10-60 prosenttia työajasta. Virtuaalinen residenssimme onkin auki hakijoille kaikista maista.

Suomalainen digitaalisen runouden kenttä on alusta asti ollut kansainvälisesti verkottunutta. Arto Kytöhongan (1944-1992) Suomen ensimmäisiin kuuluneet runogeneraattorit olivat aikanaan huomattavasti tunnetumpia angloamerikkalaisessa maailmassa kuin Suomen kirjallisuuskentällä. Marko Niemen (1974-2019) työ digitaalisen runouden saralla sekä runoilijana että tuolloin digitaaliseen, visuaaliseen ja äänirunouteen keskittyneen Nokturnon pitkäaikaisena päätoimittajana oli arvostettua alan toimijoiden keskuudessa monessa maassa. Nokturnossa nykyisin julkaistava materiaalikin koostuu edelleen sekä koti- että ulkomaisten tekijöiden teoksista. Teos- ja artikkeliehdotuksia tulee Suomen lisäksi muun muassa Uudesta-Seelannista, Intiasta, Kanadasta, Yhdysvalloista, Espanjasta ja Venäjältä. Kävijädatasta käy ilmi, että kuukausittaisten satojen lukijoiden joukossa on kävijöitä vielä paljon useammasta maasta. Nokturno onkin esimerkki julkaisukanavasta, joka on lähtökohtaisesti kansainvälinen. On toimituksellinen päätös olla erottelematta omiksi osioikseen kotimaista ja ulkomaista sisältöä ja siirtää fokus esimerkiksi teoksen edustamaan lajiin tai teemoihin.

On myös mahdollista kysyä, onko kansainvälisyyttä kuvaavampi termi elektronisen kirjallisuuden alalle sittenkin transnationaalisuus. Perinteisten kirjakustantamoiden, kuten monien muidenkin taideinstituutioiden synty on usein jäljitettävissä kansallisuuteen pohjautuviin rakenteisiin ja normeihin. Niissä kysymys kielestä ja siitä, miltä valtiolliselta alueelta kirjallisuutta julkaistaan, on toiminnan lähtökohta. Elektroninen kirjallisuus taas on usein syntynyt ja kehittynyt kansainvälisissä yhteisöissä. Lajiin myös sisältyy toteutuksen tasolla nykymuotoisen kansainvälisyyden mahdollistavaa teknologiaa havainnoivia alalajeja, kuten internetin hakupalveluita ja internetissä julkaistua materiaalia hyödyntävät generaattorit. 
Elektroninen kirjallisuus onkin parhaimmillaan post-internet -ajan taidetta. Suomessa verrattain vähän käytetty käsite on noussut laajempaan tietoisuuteen kansainvälisen visuaalisten taiteiden maailman kautta. Se viittaa aikaan, jossa internet on jo muodostunut keskeiseksi osaksi niin arkea, tiedonvälitystä, yhteiskunnan järjestäytymistä kuin estetiikkaakin. Sanan post suhde sanaan internet on yhtä ristivetoinen kuin tunnetummassa termissä postmodernismi: se viittaa sekä ilmiön ajalliseen jälkeisyyteen että sen keskeisten piirteiden toisinajatteluun ja haastamiseen. Tästä näkökulmasta hyvin monenlaisen kirjallisuuden ja taiteen voidaan siis ajatella edustavan estetiikaltaan tai teemoiltaan post-internetiä. Digitaalisia keinoja monimuotoisesti käyttävän kirjallisuuden erityinen piirre on kuitenkin sen laaja-alainen mahdollisuus tutkia aikaamme niin ohjelmoinnin, visuaalisuuden kuin tekstuaalisuudenkin näkökulmasta ja tuottaa uusia luovia tapoja olla suhteessa teknologisoituneeseen, globaaliin ympäristöömme.

\section{Kirjallisuus}

Funkhauser, C. T. 2007. Prehistoric Digital Poetry. An Archaeology of Forms, 1959-1995. Tuscaloosa, Alabama: University of Alabama Press.

Clazier, Loss Pequeño 2002. Digital Poetics: The Making of E-Poetries. Tuscaloosa, Alabama: University of Alabama Press.

Joensuu, Juri 2012. Menetelmät, kokeet, koneet: proseduraalisuus poetiikassa, kirjallisuushistoriassa ja suomalaisessa kokeellisessa kirjallisuudessa. Helsinki: Poesia. 